Stream: Inspiring Critical Thought

2018, Vol 10(2), 15-26

(C) The Author(s), 2018

http://journals.sfu.ca/stream

\title{
From the Margins to the Centre(s) of Social Change: An Exploration of the Contributions of Latin American Commu- nication Research
}

\author{
Belen Febres-Cordero \\ School of Communication \\ Simon Fraser University
}

\begin{abstract}
Latin American communication research has a long history of considering communication as a participatory and horizontal process. However, this research is not necessarily widely known in the West. This paper analyzes the work of some of the main foundational and contemporary communication scholars from Latin America, and the contributions and limitations of this body of work in relation to global communication. This paper draws mainly from the work of foundational and contemporary scholars from Latin America. To a lesser extent, it draws from the work of scholars from other countries from the West and the Global South that can inform the understanding of communication research in Latin America. An exploration of the main work and thought of some of the foundational Latin American communication scholars indicates that most of this literature has focused on empirical contributions, assessing, questioning, re-contextualizing and adapting the theories from the West to the local settings, and that less emphasis has been placed on generating unique theoretical concepts and frameworks emerging from the region. However, a review of the work of some contemporary scholars from Latin America - especially the ones focusing on participation, decoloniality and the conceptualization of the margins - suggests that there could be a shift in the focus of Latin American communication research, and the contributions that it could have to the theory and practice of global communication. The analysis of the literature indicates that the work of some of the contemporary Latin American scholars focusing on decoloniality and the conceptualization of the margins could contribute to build theoretical work emerging from the region and, in this way, help increase, re-value, and distribute the literature making unique theoretical contributions to the study of communication from Latin America. This work could have important theoretical and empirical contributions to communication research in Latin America and beyond. Future research in the region should take these considerations into account, while also studying the possibilities and limitations of emerging information technologies in different contexts.
\end{abstract}

\section{Keywords}

Latin America, decolonality, intersectionality, positionality, communication studies

\section{Introduction}

While I was conducting research about community radio stations for my Master's studies in Anthropology, I had the opportunity of working closely with a remarkable group of people conducting important empirical work on community media. I was humbled by all they had to teach me about the practice of communication and its possible contributions to listening to the communities that 
had been historically dispossessed of their voices, thereby sidelined to the margins of dominant platforms for participation, knowledge production and decision making.

This process did not only contribute to my academic growth and to my own understanding of the practice of communication; perhaps even more importantly, it made me consider my own positionality as an aspiring Latin American communication researcher. It made me question my current work and the path I want to take with it. During this time, I could not help noticing the irony of the fact that I was learning about the work that is currently being done in my own country and region of origin while I was living and studying abroad. How is it possible that this is the first time I am hearing about the work done in Latin America by Latin American scholars and communication practitioners? What are the internal and external factors that have resulted in my ignorance about these topics and contributions? I realized that these limitations were not only mine when I read the draft of the Master's thesis currently being written by one of the communicators of the radio stations I collaborated with during my studies. Despite having been deeply involved in the practice of alternative communication in Latin America for more than ten years; despite having been one of the main activists fighting for the democratization of communication in Ecuador; and despite having had the opportunity of not only interviewing and collaborating with some of the main contemporary communication scholars of the region, but also chatting over a beer with them, this person's otherwise great work on intercultural communication in the Ecuadorian Amazon region draws mainly from theories and scholars from the West. Why?

These and similar questions populated my mind almost to the point of obsession. These inquiries were accentuated during the first weeks of my doctoral studies when, after reviewing the syllabus of the undergraduate studies in Journalism I pursued in Ecuador, I realized that none of them had included a Latin American scholar. Not even one. This made me question why the work of Latin American scholars who had made important contributions to global communication, such as Paulo Freire, Nestor García- Canclini, Jesús Martín-Barbero and Luis Ramiro Beltrán, had been absent from my studies, not only at Canadian universities, but also at the Latin American ones.

This paper is inspired by these questions and by the conversations I have had with colleagues and professors since then. In these pages, I aim to explore the main contributions that some of the foundational and contemporary Latin American scholars have made and are making to the understanding and practice of communication.

Broadly considering communication as a horizontal process rather than a vertical transmission of information, Latin American communication research has greatly focused on questions about participation and communication for social change (Beltrán, 2008). Foundational communication research in Latin America focused mainly on questions around participation and the process of communication. Contemporary scholars from the region have followed this tradition, and have taken it forward by raising questions related to Decoloniality and participatory communication processes emerging from the margins (Waisbord, 2014). However, the contributions of foundational and contemporary Latin American scholars have not necessarily been taken into consideration within academic settings outside, and even inside the region (Martin-Barbero, 1993; Waisbord, 2014).

Drawing mainly from the work of foundational and contemporary scholars from Latin America and, to a lesser extent, from the work of communication scholars from the West and other countries of the Global South that inform the understanding of Latin American communication research, in this paper I study some of the main contributions of Latin American communication research to the comprehension and practice of global communication. A comprehensive overview of the literature goes beyond the scope of this paper. Rather, I focus my analysis on the main contributions of some of the foundational and contemporary Latin American communication scholars to argue that the 
contemporary work around Decoloniality and the conceptualization of the margins can contribute to build theoretical work emerging from the region and, in this way, broaden the limited body of literature from Latin America making unique theoretical contributions to communication research (Waisbord, 2014, p. 12).

With this paper, I also embark on a process of self-reflexivity that could help inform and shape my current and future work, which is partially motivated by the eagerness of contributing to change the way in which Latin American communication research is seen, taught and understood inside and outside the region.

\section{The Latin American Tradition}

One of the aspects that became clear when I first started to immerse myself in the study of communication research in Latin America was that scholars from the region have mostly contributed to the understanding of communication as a horizontal and participatory process that is geared towards social change. As such, several Latin American researchers have conceptualized communication as a democratic social interaction by which human beings voluntarily share experiences under conditions of free and egalitarian access, dialogue and participation, aiming to transform social circumstances according to local and self-identified needs (Beltrán, 2008; Gumucio-Dagron \& Tufte, 2006a; Waisbord, 2014).

Predominantly grounded on empirical work, the emphasis in Latin America has been placed on assessing, questioning, adapting, re-contextualizing and applying theories from the West within the local reality rather than generating unique theoretical contributions emerging from the struggles, knowledge(s), worldviews and traditions from the region (Waisbord, 2014). However, the work of foundational scholars has in turn influenced contemporary researchers in Latin America and has been crucial for establishing the regional tradition of communication and media scholarship (Beltrán, 2008).

A great body of work in Latin America has focused on participation and communication for development. Juan Díaz Bordenave and Paulo Freire are two of the foundational scholars along these lines of work. Both focused on questions around education, communication and participation. Much of the work of Díaz Bordenave focused on education and communication for development specifically in rural areas (Infoamérica, 2016). Similarly - and starting from a tradition based on Christian principles, which manifested itself in Latin America through the Liberation Theology - Paulo Freire focused his work on what he denominated the "Pedagogy of the Oppressed" (Freire, 1970). Freire understood pedagogy as a possible avenue to liberate individuals from the restrictions that perpetuate their oppression. He considered that education was closely linked to communication; and that alternative media, and radio in particular, could be cultural instruments to generate dialogue, collaboration and participation with and among people who have not had access to other spaces for communication and education (Infoamérica, 2016; Marín, 2012; Mato, 2004, pp. 674-5).

The work of Díaz Bordenave and Freire in particular influenced and continues to influence studies and practices around alternative communication and communication for development in Latin America. In fact, the communication put into practice by the community radio stations I worked with during the research I conducted to complete my Master's thesis relies on a great extent on Freire's insights. Similarly, some of the scholars influenced by the theories developed by Freire and Díaz Bordenave are Mario Kaplún and his work on dialogue and participation in radio plays (Infoamérica, 2016; Marín, 2012), some of which were translated to indigenous languages such as Quechua and Aymara (Infoamérica, 2016); Francisco Gutiérrez and his work around pedagogy and language in media (Utopía Educativa, 2008) ; Daniel Prieto and his work on communication and 
education (Prieto Castillo, 2016); and Luis Ramiro Beltrán, whose main contributions particularly built upon the work of communication for development, and focused on the democratization of communication and on communication for development (Infoamérica, 2016; Marín, 2012; Rogers, 1976).

Another body of foundational Latin American communication research has focused on the analysis of cultural formations and processes. Paying close attention to the political and cultural uses of the media, this work focuses more on considerations around the processes of communication than on the analysis of media texts (Waisbord, 2014, p. 3,7-8). Grounded in a cross-disciplinary analysis around mass communication and social theory, and based on topics such as media industries, cultural dynamics and media policies, this body of work was influenced by critical approaches and traditions from the West, and by the thought of Antonio Pasquali (Infoamérica, 2016), particularly by his analysis of the relation between communication and the cultural and political structure of society; and by his distinction between information, characterized by unidirectionality, and communication, which entails reciprocity (Infoamérica, 2016; Martín-Barbero, 2008).

Three of the main foundational scholars working along these lines are Néstor García-Canclini, whose work on hybrid cultures and complex dynamics of cultural traditions contributed to the understanding of global communication; Armand Mattelart, whose work on media messages and ideology contributed to the analysis of the unequal process of message production in society (MartínBarbero, 2008; Mattelart, 1996); and Jesús Martín-Barbero, who contributed to rethink the relationships between communication, media and culture, understanding communication as a process of mediations and arguing that, rather than the analysis of media texts, the study of communication should focus on the contexts and processes where people develop a sense of self and common bonds, and appropriate and re-signify media messages (Martin-Barbero, 1993; Infoamérica, 2016; Marín, 2012; Waisbord, 2014). Their contributions influenced Latin American scholars such as Guillermo Orozco Gómez and his work on reception studies and audiovisual literacy (Infoamérica, 2016). However, once again, the important contributions of these authors were not present in my undergraduate curriculum, even though I took three courses specifically focusing on critical cultural studies.

In the following sections I explore how the work of contemporary Latin American scholars focusing on theories of decoloniality and the conceptualization of the margins could help us understand why Latin American authors have not been included enough in communication studies both inside and outside the region. In addition, I analyze how theories of decoloniality could begin to generate unique theories emerging from the local knowledge while simultaneously informing empirical research designs within its specific context.

\section{Decoloniality and the Margins}

The work of some contemporary Latin American scholars like Anibal Quijano, Walter Mignolo, Arturo Escobar, Santiago Castro-Gómez and Nelson Maldonado-Torres has focused on questions around Coloniality, decoloniality and the conceptualization of the margins (Álvarez Solís, 2010, p. 95; Infoamérica, 2016; Lander, 2000; W. D. Mignolo, 2005; Que de Libros, 2008, p. 10; Universidad Rafael Landívar, 2016).

Although some of the influence for this literature came from critical scholars from the West, such as Emmanuel Levinas and Max Horkheimer (Berendzen, 2013; Horkheimer, 2002), this body of work has major influences from the contributions of Latin American thought, such as the Liberation Theology of Enrique Dussel and others (Dussel, 1988), and the considerations expressed by José Carlos Mariátegui on his essays on the interpretation of the Peruvian reality (Biografías y Vidas, 
2004; Mariátegui, 1928). This body of work also draws from the contributions of scholars from other regions of the Global South, such as Aimé Césaire and Frantz Fanon with their considerations related to the colonial experience and its racial dimensions (Biografías y Vidas, 2004; Fanon, 2004; Maldonado-Torres, 2007; W. Mignolo, 2011; Universidad Rafael Landívar, 2016).

The concept of decoloniality emerged in the early 1990s (Álvarez Solís, 2010). It starts from making a distinction between colonialism and coloniality. It understands colonialism as the political and economic relation in which the sovereignty of a nation or a group of people rests on the power of another nation. Colonialism, then, is a historical process that ends with the withdrawal of direct administrations from colonialized geographical locations ( Mignolo, 2009; Mignolo, 2012; NdlovuGatsheni, 2013, p. 13). On the other hand, coloniality is understood as the long-standing patterns of power that emerged as a result of colonialism, but that are still present and define the culture, labour, human relations and knowledge production beyond the limits of colonial administrations (Maldonado-Torres, 2007, p. 243; Ndlovu-Gatsheni, 2013, p. 13).

In these terms, decoloniality refers to "the realization that ours is an asymmetrical world order that is sustained not only by colonial matrices of power but also by pedagogies and epistemologies" (Ndlovu-Gatsheni, 2013, p. 13). Therefore, it argues that coloniality continues to exist in the lives, languages, practices and epistemologies of the Global South, and that it is perpetuated by the dominant means of production, knowledge production and dissemination (Maldonado-Torres, 2007, p. 243; Ndlovu-Gatsheni, 2013, p. 11).

Decoloniality is based on three main concepts. The first concept is the Coloniality of Power, which focuses on the way in which "the global political was constructed and constituted into the asymmetrical and modern power structure" (Ndlovu-Gatsheni, 2013, p. 11). The second concept is the Coloniality of Knowledge, which focuses on the way in which epistemologies are constructed, and questions the means, objectives and outcomes of knowledge production and dissemination (W. Mignolo, 2012; Ndlovu-Gatsheni, 2013, p. 11). The third concept is the Coloniality of Being, which focuses on the way in which coloniality is embodied, experienced and articulated in terms of subjectivity and the colonial being (Maldonado-Torres, 2007, p. 242; Ndlovu-Gatsheni, 2013, p. 12).

These considerations help understand the margins as spaces of political, social, economic, symbolic, geographic and epistemic exclusion (Castro-Gómez, 2007; Fonseca \& Jerrems, 2012, p. 115). Similar to Western critical theories (Horkheimer, 2002), decoloniality considers that the knowledge(s) of the colonized geographic locations have been historically consigned to the margins of dominant platforms of means of production, knowledge production and knowledge dissemination. Therefore, it calls for a de-hegemonization and de-Westernization of knowledge (NdlovuGatsheni, 2013, p. 15). A scholar that has made important contributions in this regard is Boaventura de Sousa Santos (Portugal, 1940). Although he was not born in a Latin American country, he has contributed to the thought of decoloniality in the region with concepts such as the Epistemologies of the South and the Rearguard Theory (De Sousa Santos, 2014). With these, he argues that to achieve social justice, cognitive justice - or the re-legitimatization of the historically excluded knowledge(s) of the oppressed social groups - is fundamental (De Sousa Santos, 2012, pp. 144-5).

In this way, the theories of decoloniality can drive us to consider the different powers that have influenced how knowledge is produced and disseminated both inside and outside Latin America, and start to bring attention to the reasons why knowledge and scholarship produced in the region have not been valued to the same extent to the one produced elsewhere. In addition, these theories raise further interrogations, such as: How can the work of Latin American scholars contribute to achieve cognitive justice both inside and outside the region? What exactly does it mean to listen to the voices from the margins, and what kinds of research designs are required to do so? I explore some of these questions in the following sections. 


\section{Decoloniality in Practice and Theory}

Theories of decoloniality and the conceptualization of the margins could inform participatory research designs geared towards social change while simultaneously contributing to generate and value the unique theoretical contributions from Latin America.

Decoloniality can contribute to inform research designs by driving scholars and communication practitioners to carefully consider what it means to listen to the voices and knowledge(s) that have been historically consigned to the political, social, economic, symbolic, geographic and epistemic margins, and to craft the best research designs to listen to such voices.

These considerations can inform the work of contemporary Latin American communication scholars - such as Fernando Reyes-Matta, Alfonso Gumucio-Dargon, Rafael Obregón Gálvez, Mario Mosquera, Mauro Cerbino and Robert Huesca - conducting research around alternative communication and communication for social change, largely influenced by the legacy of Paulo Freire and Orlando Fals Borda and his work on Participatory Action Research in Latin America (Herrera Angel, n.d.; Infoamérica, 2016; Mato, 2004, p. 675; Obregón, 2014).

By taking into consideration the historical processes of exclusion and continuous coloniality, communication scholars in Latin America could turn to the geographic, symbolic, political and epistemic margins where oppressed individuals and communities have been consigned. By doing so, they could pay attention and contribute to render visible the verbal and non-verbal modes of communication - such as songs, strikes, dances, street protests and performances - that they have found to express themselves in view of their erasure from hegemonic spaces for communication and participation (Conquergood, 1991; Dutta, 2011; Febres-Cordero, 2015; Madison, 2012; McLaughlin, 1993, p. 605). Hence, empirical participatory research designs based on decoloniality could be geared towards the co-creation and the strengthening of participatory spaces for these expressions to take place (Febres-Cordero, 2015). These designs should also consider the possible contributions that new information technologies could offer to these participatory processes in the Latin American context. As Silvio Waisbord (2014) suggests:

This is an appropriate subject to study in Latin America, not only given recent examples of using digital platforms for contesting power and organizing citizens - from student activism to citizens' mobilization against extractive projects along the region. It is also a relevant issue given the region's pioneering tradition of alternative uses of various media (from radio to grassroots video) for political empowerment (p. 15).

The physical and virtual co-creation and strengthening of these spaces for participation could contribute to bring their voices, worldviews and knowledge(s) to the centre(s) of political, economic, symbolic and epistemic platforms, from where they could work towards social and structural shifts geared towards social change (Febres-Cordero, 2015; Gumucio-Dagron \& Tufte, 2006b).

Decoloniality could also rectify the dearth of contributions and validation of unique conceptual and theoretical frameworks in Latin America (Waisbord, 2014). Through the empirical collaboration and participation with marginalized communities, communication scholars from the region could start to build theoretical frameworks and epistemologies emerging from the local knowledge(s), cosmologies and worldviews (De Sousa Santos, 2014). Indigenous worldviews such as the Sumak Kawsay in Ecuador and the Sumak Qamaña in Bolivia could set the bases of such frameworks. 
Sharing similar core values with other concepts of the Global South, such as the Pan-African concept of Ubuntu, the concepts of Sumak Kawsay and Sumak Qamaña are based on principles of solidarity, complementarity, reciprocity and respect, among others (Baldi, 2013; Kamwangamalu, 2014).

Translated into English as "Good Living", these concepts are located within the Andean indigenous cosmology and refer to the understanding of life as a cyclical and continuous process (Baldi, 2013). They present an alternative to the Western understanding of development by emphasizing the need for living in harmony with oneself, the community and the environment (Baldi, 2013; Febres-Cordero, 2015, p. 91; Guerrero Arias, 1993, p. 76; Simbaña, 2012, p. 225). Concepts such as the Sumak Kawsay and Sumak Qamaña could contribute to question and contest the historic imposition of Western traditions, worldviews and modes of life (Arellano Ortiz, 2013; Montilla, 2013, pp. 159-160). In addition, they could offer an alternative way of thinking and living emerging from the region, which could also inform new theoretical frameworks around development, communication and, specifically, communication for social change, while also challenging the systemic exclusion of this type of knowledge from academic settings. In other words, theories of decoloniality could help us analyze if and how coloniality pierces the practice and study of communication both inside and outside academic settings in Latin America and beyond.

\section{Self-Reflexive Notes on Intersectionality and Contemporary Latin American Communication Research}

My positionality within the subject matter makes it impossible for me to distance myself from the topic of this paper. As an aspiring Latin American communication scholar, I feel that the exploration of contemporary communication research in the region would not be complete without the following self-reflexive considerations.

Writing this paper was a difficult endeavor for me, not only because most of the previous knowledge on communication I had been exposed to came from the West and I made a conscious effort to mainly draw upon the contributions of Latin American scholars for this work, but also because it signified a process of self-reflexivity in which I have arrived to some sad observations. However, I have also realized that the theories of intersectionality (Crenshaw, 1989, 1991) could offer a possible avenue to look for solutions.

The term intersectionality was first introduced by the critical scholar Kimberlé Crenshaw (United States, 1959) in her text Demarginalizing the Intersection of Race and Sex: A Black Feminist Critique of Antidiscrimination Doctrine, Feminist Theory and Antiracist Politics (Crenshaw, 1989; Hankivsky, 2014). This term:

Promotes an understanding of human beings as shaped by the interaction of different social locations (e.g., 'race'/ethnicity/Indigeneity, gender, class, sexuality, geography, age, disability/ability, migration status, religion). These interactions occur within a context of connected systems and structures of power (e.g., laws, policies, state governments and other political and economic unions, religious institutions, media). Through such processes, interdependent forms of privilege and oppression shaped by colonialism, imperialism, racism, homophobia, ableism and patriarchy are created (Hankivsky, 2014, p. 2).

Intersectionality can complement decolonial considerations by analyzing the way in which the 'multi-dimensional and complex social locations, power relations and experiences' (Hankivsky, 2014, pp. 2-3) of historically marginalized individuals and communities intersect and shape their 
realities. With these considerations, intersectionality can contribute to change some of the current realities of Latin American communication scholars I have recognized in the process of writing this paper.

The first realization I had was that the contemporary Latin American scholars that are relatively known inside and/or outside Latin America are, almost exclusively, men. The erasure of women's presence in communication research in Latin America was particularly evident for me when analyzing the work of Armand Mattelart. Although much of his work was conducted in collaboration with his wife, Michèle Mattelart (Mujeres en Red, 2016), and although she has made other important contributions, particularly around questions regarding gender and communication in the region (Porta, 2006), she was barely mentioned in a few of the texts I consulted, and not mentioned at all in most of them. Intersectionality could contribute to analyze the layered reasons that may be limiting the accessibility to and/or the production of women's work, as well as the legitimization of their contributions within academia. These reasons could respond to multiple forms of gender-based oppressions of structural, social, material, symbolic and epistemic inequalities that exclude them from public spheres - discursive spaces where 'private citizens debate issues of public concern and engage in criticism in an environment free of power relations'(McLaughlin, 1993, pp. 600-601, 612) and from other spaces for participation and knowledge production. These oppressions can be related to gender and gender norms; class; 'race'/ethnicity; and gendered geographical, political and academic locations, among others.

I also noticed that these authors write or translate their work into English, live or have lived outside the region, and work or have worked in Western academic settings. Both decoloniality and intersectionality can contribute to understanding the historical and contemporary reasons for this reality. Most of the work being created and/or distributed in English may respond to the margins in terms of language and knowledge production and distribution. This may result in research conducted and distributed in Spanish or Portuguese not reaching readers outside these margins, and this may also mean that the theories and work created in English may not reach and help inform the work of scholars writing in other languages. The fact that most of the known contemporary Latin American scholars reside in Western countries and work in Western universities may relate both to language and to the possibility that the validation of knowledge production is done within Western limits and standards.

My third observation was that while there are some relatively known scholars from several Latin American countries such as Brazil, Argentina, Colombia and Bolivia, there are almost no known Ecuadorian communication scholars. This is particularly surprising given that several of the regional organizations and networks working on communication are based in Ecuador's capital city (Febres-Cordero, 2015). Intersectionality argues that privilege and oppression are not mutually exclusive (Hankivsky, 2014, p. 3). This drives me to think that we could consider the margins as heterogenous rather than homogenous geographic, symbolic, social, economic, political, and epistemic spaces of exclusion.

Considerations of this kind should be explored and addressed when thinking about contemporary communication research in the Global South, and in Latin America in particular (Mato, 2004, pp. 677-8), and the way in which this research is valued, produced, and distributed in academic settings. Despite the possible limitations that this approach could have, theories emerging from the margins, such as intersectionality and decoloniality, could offer a possible avenue to do so. 


\section{Conclusions}

In this paper, I have explored the work of some of the main foundational and contemporary communication scholars from Latin America, and the contributions and limitations of this body of work in relation to global communication.

Rather than offering a comprehensive overview of the Latin American contribution to communication research, I have focused on some of the main literature from the region to argue that Latin American communication scholarship has been particularly interested in empirical work; and that it has critiqued, re-contextualized and adapted the theoretical contributions of the West to the local reality.

The review of the work of some contemporary scholars from Latin America focusing on questions around decoloniality, participation and the conceptualization of the margins has served to suggest that there could be a shift in the focus of Latin American communication research. This body of literature could contribute to build theoretical work emerging from the local knowledge(s), worldviews and cosmologies of the region, while simultaneously informing empirical contributions and participatory research designs geared towards social change. Such research designs should take into consideration the contributions that the new information technologies could have when putting this objective into practice.

Finally, I have claimed that the exploration of contemporary communication research in Latin America would not be complete without the analysis of the gender, geographic location and language of the existing scholars and literature from the region. I have suggested intersectionality as a possible avenue to complement the theories of decoloniality and the margins emerging in Latin America to better understand and address these observations, and to shed light into the several reasons why the important contributions made by scholars from the region have been excluded from academic settings both inside Latin America and abroad.

Based on the contributions of Latin American scholars, I have proposed to understand the margins as heterogenous geographic, symbolic, social, economic, political and epistemic spaces of historic and contemporary exclusion. It is from these heterogenous margins where new theories, concepts, participatory research designs and communication practices could and should emerge. The knowledge that still resides on the margins from and within Latin America, I believe, is the main contribution that contemporary communication research in and from the region has to offer. By bringing the voices, knowledge(s) and worldviews that have remained silenced to the centre(s) of knowledge production, Latin American communication research could help envision some possible avenues towards social change both inside and outside its margins.

\section{References}

Álvarez Solís, Á. O. (2010). La persistencia de los márgenes. Reflexiones epistemológicas en torno a la obra de Walter Mignolo. Araucaria: Revista Iberoamericana de Filosfía, Política Y Humandades, 12(23), 94-144.

Arellano Ortiz, F. (2013). Arturo Escobar: "La alternativa al modelo hegemónico de desarrollo capitalista es el concepto del buen vivir." Retrieved from http://connuestraamerica.blogspot.ca/2013/11/arturo-escobar-la-alternativa-al-modelo.html

Baldi, C. A. (2013, April 15). Sumak Kawsay, Interculturality and decolonialization. Retrieved from http://criticallegalthinking.com/2013/04/15/sumak-kawsay-interculturality-anddecolonialization/ 
Beltrán, L. R. (2008). Development communication: Latin America. In D. Wolfgang, J. Bryant, \& R. T. Craig (Eds.), International encyclopedia of communication. Retrieved from https://onlinelibrary.wiley.com.

Berendzen, J. C. (2013, July 21). Max Horkheimer. In E. N. Zalta (Ed.), The Stanford Encyclopedia of Philosophy. Retrieved from http://plato.stanford.edu/archives/fall2013/entries/horkheimer/

José Carlos Mariátegui. (n.d.). In Biografías y vidas: La enciclopedia biográfica en línea. Retrieved from https://www.biografiasyvidas.com/biografia/m/mariategui.htm

Castro-Gómez, S. (2007). Michel Foucault and the coloniality of power. Tabula Rasa, 6, 153-172.

Conquergood, D. (2006). Rethinking ethnography: Towards a critical cultural politics. D.S. Madison \& J. Hamera (Eds.), The SAGE Handbook of Performance Studies (pp. 179-194). Thousand Oaks, CA; London, New Delhi: Sage Publications, Inc.

Crenshaw, K. (1989). Demarginalizing the intersection of race and sex: A black feminist critique of antidiscrimination doctrine, feminist theory and antiracist politics. University of Chicago Legal Forum, 1(8), 139-167.

Crenshaw, K. (1991). Mapping the margins: Intersectionality, identity politics, and violence against women of color. Stanford Law Review, 43(6), 1241-99.

De Sousa Santos, B. (2012). De las dualidades a las ecologías. La Paz: Imprenta Punto de Encuentro. Retrieved from http://data.over-blogkiwi.com/1/38/03/91/20160308/ob_3fb912_boaventura-de-sousa-santos-de-las-dua.pdf

De Sousa Santos, B. (2014). Epistemologies of the south: Justice against epistemicide. New York, NY: Routeledge.

Dussel, E. (1988). Teología de la Liberación y Marxismo. Unam-Universidad Autónoma Metropolitana, México, 138-159. Retrieved from https://www.scribd.com/document/79421711/Dussel-Enrique-Teologia-de-la-liberacion-ymarxismo

Dutta, M. J. (2011). Communicating social change: Structure, culture, agency. New York, NY: Routledge.

Fanon, F. (2004). The wretched of the earth. New York, NY: Grove Press.

Febres-Cordero, B. (2015). Radio beyond voice: Understanding community radio stations in Ecuador through performance (master's thesis). Simon Fraser University, Vancouver, CA.

Fonseca, M., \& Jerrems, A. (2012). Pensamiento decolonial: ¿una "nueva" apuesta en las Relaciones Internacionales? Relaciones Internacionales, 19, 103-121.

Martin-Barbero, J. (1993). Communication, culture and hegemony: From the media to the mediations. Thousand Oaks, CA: SAGE.

Freire, P. (2006). Pedagogy of the oppressed. In A. Gumucio-Dagron \& T. Tufte (Eds.), Communication for social change anthology: Historical and contemporary readings (pp. 44-48). South Orange, NJ: Communication for Social Change Consortium.

Guerrero Arias, P. (1993). El Saber del Mundo de los Cóndores: Identidad e Insurgencia de la Cultura Andina. Qutio, EC: Ediciones Abya-Yala.

Gumucio-Dagron, A., \& Tufte, T. (2006). Roots and relevance: Introduction to the CFSC anthology. In A. Gumucio-Dagron \& T. Tufte (Eds.), Communication for social change anthology: Historical and contemporary readings (pp. xiv-xxxvi). South Orange, N.J: Communication for Social Change Consortium.

Hankivsky, O. (2014). Intersectionality 101. The Institute for Intersectionality Research \& Policy, SFU. Retrieved from http://vawforumcwr.ca/sites/default/files/attachments/intersectionallity_101.pdf 
Herrera Angel, M. (n.d.). Fals Borda Orlando. Retrieved from http://www.banrepcultural.org/blaavirtual/biografias/falsorla.htm

Horkheimer, M. (2002). Traditional and critical theory. In Critical theory: Selected essays (M.J. O'Connell trans.), (pp. 188-245). New York, NY: Continuum Publishing.

Infoamérica. (2016, November 13). Perfil Biográfico y Académico. Retrieved from http://www.infoamerica.org/

Kamwangamalu, N. M. (2014). Ubuntu in South Africa: a sociolinguistic perspective to a pan-African concept. In M. K. Asante, Y. Miike, \& J. Yin (Eds.), The Global Intercultural Communication Reader (2nd Ed.). New York, NY: Routledge.

Lander, E. (2000). La colonialidad del saber: Eurocentrismo y ciencias sociales. Perspectivas latinoamericanas. Buenos Aires, AR: CLACSO.

Madison, D.S. (2012). Critical Ethnography: Method, Ethics, and Performance. Thousand Oaks, CA: Sage Publications, Inc.

Maldonado-Torres, N. (2007). On the coloniality of being: Contributions to the development of a concept. Cultural Studies, 21(2), 240-270.

Mariátegui, J. C. (1928). Siete Ensayos de Interpretación de la Realidad Peruana. Lima, PE: Minerva.

Marín, A. (2012). Estudios de Comunicación en América Latina. Retrieved from http://teoriasdecomunicacionlatinoamericanas.blogspot.ca/

Martín-Barbero, J. (2008). Communication as an academic field: Latin America. The International Encyclopedia of Communication, 1.

Mato, D. (2004). Communication for social change in Latin America: contexts, theories, and experiences background and purpose. Development in practice, 14(5), 673-679.

Mattelart, A. (1996). The Invention of Communication. Minneapolis, MN: University of Minnesota Press.

McLaughlin, L. (1993). Feminism, the public sphere, media and democracy. Media, Culture and Society,15(4), 599-620.

Mignolo, W. (2011, October 28). Modernity and decoloniality. Oxford Bibliographies in Latin American Studies. Retrieved from http://www.oxfordbibliographies.com/view/document/obo9780199766581/obo-9780199766581-0017.xml\#obo-9780199766581-0017-bibItem-0001

Mignolo, W. (2012, May 2). Delinking, decoloniality \& dewesternization: Interview with Walter Mignolo (Part II). Critical legal thinking. Retrieved from http://criticallegalthinking.com/2012/05/02/delinking-decoloniality-dewesternizationinterview-with-walter-mignolo-part-ii/

Mignolo, W. D. (2005). The Idea of Latin America. New York, NY; Oxford, UK: Wiley-Blackwell Publishing.

Mignolo, W. D. (2009). Introduction: Coloniality of power and de-colonial thinking. In W. D. Mignolo \& A. Escobar (Eds.), Globalization and the Decolonial Option (pp. 1-21). London, UK: Routledge.

Montilla, A. (2013). Díaz Bordenave: "En Latinoamérica respetamos demasiado la teoría de los países desarrollados." QUÓRUM ACADÉMICO, 10(1), 155-164.

Mujeres en Red. (2016). Michèle Mattelart. Retrieved from http://www.mujeresenred.net/spip.php?auteur489

Ndlovu-Gatsheni, S. J. (2013, February). Why Decoloniality in the 21st Century? The Thinker, 10-16. Retrieved from http://www.thethinker.co.za/resources/48 Thinker full mag.pdf

Obregón, R. (2014). Comunicación, desarrollo y cambio social. Portalcomunicación.com, 1-8. Retrieved from http://www.portalcomunicacion.com/uploads/pdf/49_esp.pdf

Porta, M. (n.d.). Mujeres e industrias culturales. Michèle Mattelart: La cultura de la opresión femenina. Retrieved from http://www.nodo50.org/mujeresred/spip.php?article693 
Prieto Castillo, D. (2016). Daniel Prieto Castillo. Retrieved from http://prietocastillo.com/el-autor Que de Libros. (2008). Quijano Anibal Retrieved from http://www.quedelibros.com/autor/7369/Quijano-Anibal.html

Rogers, E.M. (1976). Communication and development: The passing of the dominant paradigm. Communication Research 3(2), 213-240.

Simbaña, F. (2012). El sumak kawsay como proyecto político. In S. Jarrín (Ed.), Más allá del Desarrollo (pp. 220-256). Quito, EC: Ediciones Abya-Yala.

Universidad Rafael Landívar. (2016, October 8). Nelson Maldonado-Torres. Retrieved from http://pensla.blogspot.ca/2016/10/nelson-maldonado-torres-nelson.html

Utopía Educativa. (2008). Francisco Gutiérrez: La pedagogía de la comunicación. Retrieved from http://seres-utopicos.blogspot.ca/2008/12/francisco-gutirrez-la-pedagoga-de-la.html

Waisbord, S. (2014). United and Fragmented: Communication and Media Studies in Latin America. Journal of Latin American Communication Research, 4(1), 1-23. 